\title{
Social Work Practice With Local Communities In Balochistan: Essential For Political Engagement
}

\author{
Siraj Bashir \\ Department of Social Work \\ University of Balochistan \\ Muhammad Faisal Zia \\ Department of Social Work \\ University of Karachi \\ Naheed Abrar \\ Department of Social Work \\ Federal Urdu University of Arts Science \& Technology
}

\begin{abstract}
The article argues a variety of characteristics of social work, wide community practice movements, and necessities for political engagement in local communities in Balochistan. Drawing on secondary knowledge and also the author's observations and analysis on community development in Balochistan, it highlights a question: do social work practice in local communities typically, and notably through political engagement? The analysis shows wide community practice movements in Balochistan and argues that social work and their profession are practically absent in local communities, and after they are thus engaged, most of them don't interact politically. Insight of local communities' backgrounds and people's depressing circumstances, the very important for social work to interact politically in community practice are mentioned. These are as follows: holding to values social work practice with communities, creating access and gaining acceptance, awareness-raising and capability building, difficult artful and oppressive community power structures, and make certain property community development. Finally, it's argued that too with success address these necessities, social work might have to alter its non-political and non-religious unbiased stand, wherever appropriate. In several conditions, social workers have to be compelled to specialize in the profession's basic values and principles and keenly interact with local politics and power structures so on improving the living conditions of individuals and local communities in Balochistan.
\end{abstract}

Keywords: Social Work, Local Communities, Political Engagement, Balochistan.

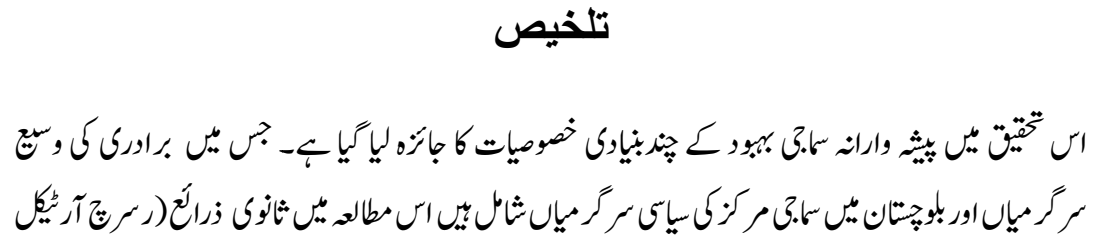

This work is Licensed under a Creative Commons Attribution-NonCommercial 4.0 International License (cc) (†) (8) 


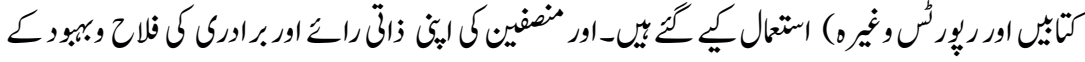

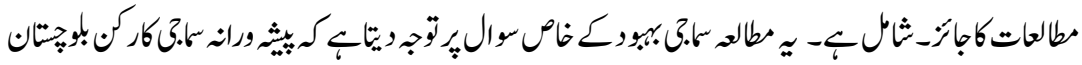

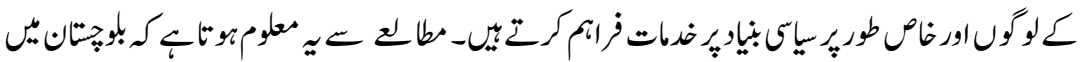

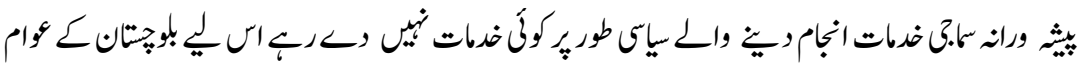

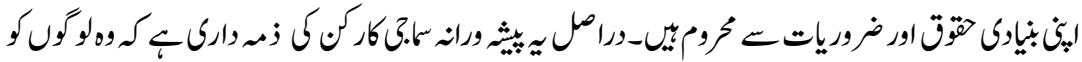

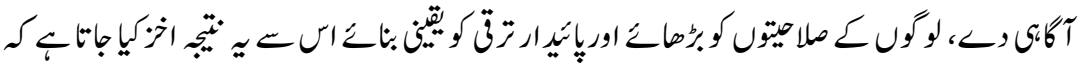

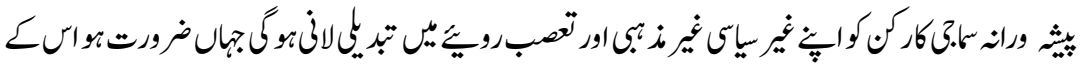

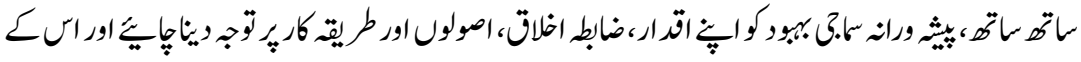

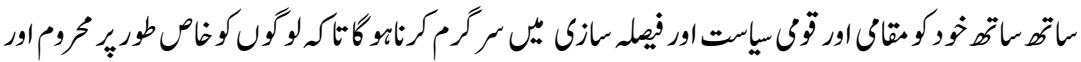

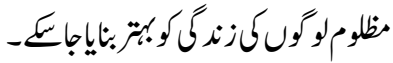

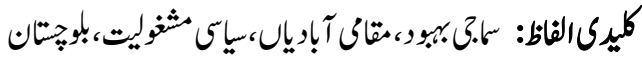

\section{Introduction}

Social work is a professional and academic discipline that committed to improving the quality and prosperity of individuals, groups, and communities through scientific knowledge, policy, community organizing, direct practice, and teaching. The Social Work encourages individuals, groups and communities for social and political changes, tries to help people to solve their problems and improve the living standard and promotes people to take self-initiative for community development and welfare (IFSW, 2000).

Social work is considered a socially adapted profession, which serves humanity for social change and mostly focuses on deprived and needy people who cannot handle their issues. The fundamental goal of social work is to provide services through scientific ways in which people become enable to manger their individuals, groups and communities matters. Social work is a skilled and professional service to individuals, groups and communities for helping them, a personal or in teams, to realize satisfying relationships and standards of life in accordance with those of the community (Gray \& Webb, 2009).

Social work practice is committed to promote social welfare, social change, social justice, social equality and empowerment of people to develop well-being. The key aim is to improve the quality of life and development of each individuals, group and community of a society. The basic principles of social work based on human rights and democratic values. As Hoefer, R. (2005) stated that social work 
is organized disincline to develop the social conditions of a community and provide possible atmosphere to people to solve their social, economical and political problems.

The education and practice of social work take place thought-out the World. According to Gray,(2005), it has an outreach around 3300 schools, colleges and universities in over 114 countries in the World. It is also practice by national and international organizations for community development programs (Pawar, 2006). Through social work education, students get knowledge, skills and various models to enable individuals, groups and communities to handle the situation and make a balance with the environment.

The objective of social work education is to teach the integration of social work knowledge, attitudes and skills, relevant to the contemporary social realities, in the historical context and local social realities, in the national and international context. Social work education also focuses on the development of a critical consciousness in students, through a process of critical pedagogy, so that they become aware of the social ills of society and are motivated to alleviate them. The approach used is student centered dialogical classroom teaching-learning, selfstudy, supervised field work practicum and practice-based research (Lee, 2001).

The political concept of social work comes from the activities in which social worker use to reduce or remove social injustice and social evils in the society (Ife, 1997). Social workers have very essential role in social welfare formulation. The idea was developed from the radical movement where it was realized that social workers commitment in the political process is very important (Corrigan, 1978). The movement, overall involved consciousness-raising efforts for empowerment, social action and policy analysis (Mullaly, 1993).

A number of writers and social workers have given attention to the importance of social work's participation in political processes throughout the world and their present can contribute very positive results for the communities (Ntusi, 1998). Poverty, injustice, and other social problems give energy to social workers to become engaged in political action, which can develop several parts. The recent concept of the political part of social work has been linked with human rights. Human rights are the key basic practice, developing the basis of social work codes of ethics and values (Gaha, 1999). Within this conversation, the basic question is how social workers respond to human rights violations and raise voices for social justice.

The social work profession promotes social change, problem solving in human relationships and empowerment and liberation of people to enhance well being, vitalizing theories of human behavior and social systems. Social work intervenes 
at the point where people interact with their environments. Principles of human rights and social justice are 'fundamental to social work' (IFSW, 2000a). Social Work appeared as a great response in the 18th and 19th centuries in western countries when whole societies transformed industrialization and urbanization and people were facing a number of social crisis. To handle the situation, state social welfare activities started different fields such as education, health, correction and etc in the 19th century in western countries. At the beginning the social work activities were financed by philanthropic people and agencies (Johnson, 2004).

Social work as a professional and knowledgeable field of practice in Pakistan. It currently usually referred to as a profession failed to build. This is often still less standard than different professions outlined set of skills to remainder of the body continues. However, a lot of suitably by different work with skilled coaching and demand may be performed by service functions that a specific field has not recognized a general social work. The role of social worker regarding political engagement is not appreciable in Pakistan and social workers do not motivate general people about their basic rights and projects. Therefore, their participation in different projects is very low.

The basic purpose of this research study is to know social workers role in local communities in Balochistan, it is very essential to provide political sense to the people while implementing community development programs or addressing communities needs and issues. Secondly, it is incredibly important to change the general role of social workers in communities, that social work is non-political and non-religious in practice while focusing as a substitute on the basic rules of human rights and social justice. To confirm this statement, the study verified some essential thoughts related to this research study; talks on the some aspects of social work; examining various books, research papers and other related literature documents of several scholars and observes community development practice in Pakistan, particularly in Balochistan, this study concluded that social work has completely neglected in national as well as in Balochistan. Additionally, it is also very important to know why social work practice essential to engage people politically in local communities in trying to improve the living standard of people and socio-economic conditions.

\section{Review of Literature}

\section{Typologies of Social Work Roles}

Social workers play a number of roles. Recently, some roles has been defined by' The college of Social Work', the college key purpose is to develop social work is a professional in the world. The following basic roles are; 
- Social workers have very enormous variety of legal and social work skills and knowledge to help and assistant people to make changes in their lives.

- They are a joint profession, working alongside other professionals but taking the lead in helping children, adults and families improve and gain control of their lives when their safety or ability to participate in their communities is restricted;

- Social workers a front line role to support people who might be disable socially, neglected or who are deprived for many other reasons. They provide support and assistance to cope with the specific situations and contribute for family, society and etc (Carey \& Foster,2011)

Payne (2005) and Dominelli(2009), divided social work interventions into three basic aspects that connect with each other. The table No.1 shown the typologies roles of social workers.

Table: 1

Typologies of social work roles

\begin{tabular}{|l|l|l|}
\hline Author & \multicolumn{1}{|c|}{ Role } & \multicolumn{1}{c|}{ Description } \\
\hline $\begin{array}{l}\text { Payne } \\
(2005 \mathrm{a})\end{array}$ & Therapeutic & $\begin{array}{l}\text { The procedure of communication and } \\
\text { reflexiveness between the social worker and } \\
\text { 'clients' which directs to clients' getting control } \\
\text { over their have sentiments. }\end{array}$ \\
\cline { 2 - 3 } & Transformational & $\begin{array}{l}\text { Empowering deprived and oppressed citizens to } \\
\text { acquire part in a process of communal } \\
\text { co } \square \text { operation and learning. }\end{array}$ \\
\cline { 2 - 4 } & Social order & $\begin{array}{l}\text { Meeting people needs during a period of } \\
\text { difficulty so they can recover stability again. }\end{array}$ \\
\hline Dominelli & Maintenance & $\begin{array}{l}\text { Aims to advance people adaptation to } \\
\text { circumstances. Support is given on the basis of } \\
\text { obviously defined criterion. }\end{array}$ \\
\cline { 2 - 4 } & Therapeutic & $\begin{array}{l}\text { An off } \square \text { shoot of the maintenance approach but } \\
\text { center on what an person can do to advance his } \\
\text { or her circumstances through targeted } \\
\text { professional interventions. }\end{array}$ \\
\cline { 2 - 4 } & Emancipatory & $\begin{array}{l}\text { This is associated with radical social work and } \\
\text { questions the current balance of control in } \\
\text { society and sharing of supplies. Actions are } \\
\text { aimed both at helping individuals and achieving } \\
\text { structural change. }\end{array}$ \\
\hline
\end{tabular}




\section{Social Work's Political Role}

Social work basically related with social change and social justice. As The International Federation of Social workers (2000b) defined that social work focuses for social justice and equality for people and struggles for social change and empowers the people and communities. It considers "principle of human rights and social justice, as being the key for social work. Special focus has been given to the importance and need for social worker to play an active role in political area (Ntusi, 1998a). As Gray (2005a), said that political action is an action taken by social workers to struggle for social change and development. In this regard, political action includes all those activities which are linked with social change, such as empowerment, justice, advocacy and to the legislative processes that have an power on people's lives. In this research study, particular concentration is given to political participation by social workers in relation to local communities.

There are also more social policies that impact on our work with clients, consisting of policy regarding education, housing, social security, social welfare, unemployment, development, etc. Thus whilst we speak approximately coverage in social work we talk approximately social people being aware of and gaining knowledge of to engage with policy methods in society because social employees implement policy. Their stage of involvement in policy implementation will differ relying on the context in which they may be operating. For instance, the ones working for government corporations might be extra at once worried in policy implementation than the ones working in grassroots community organizations. Social employees also interact in coverage-making processes and try to trade unjust policies. Thus policy and politics pass collectively. When we interact with policy-making processes, whether or not we're implementing, making or trying to exchange policy, we're concerned in politics, inside the manner in which current policy serves to maintain the gadget and gain compliance with social norms.

The procedure they grow to behave interaction in to put off social justice is political. This is the very best feel of social paintings' political involvement. In expertise the political involvement of social people in this studies study, we have been keenly inquisitive about social workers' attention of social policy, the manner they engaged in coverage-making tactics, the way they conflict to persuade guidelines. In this regard, it may attempt to recognize social workers were privy to social regulations, had examined coverage files, replied to them, served on committees or were worried in procedures that contributed to their making.

\section{Community Practice Approaches}

Community practice may be categorized into five approaches. The first approach, 
community-driven development (CDD), has been named, designed, and implemented by mainly the World Bank (2009), which claims that this approach "gives control over planning decisions and investment resources to community groups and local governments by following the principles of local empowerment, participatory governance, demand responsiveness, administrative autonomy, greater downward accountability, and enhanced local capacity." The main areas of activity within CDD are micro-finance, a disability focus, youth inclusion, natural resource management, and urban development (UNO, 1997).

Second, some non-government organizations, and some others use a rights-based approach, which aims to realize human rights by laying the emphasis on rights and responsibilities and human dignity rather than charity, and by directly addressing the causes of poverty. It is based on the ethical stand that all human beings are entitled to certain minimum standards. Third, the asset-based approach is essentially a strength-based approach that recognizes and builds on existing communities' assets, which mainly include the assets of individuals and groups, local associations and institutions, the local physical aspects and economy, and formal and informal relationships, skills, and capacities among all participants. It is very much rooted in the local setting and aims to use such assets for community development rather than being preoccupied with needs and problems (Harris Rome, 2010). It is generally used by the U.S. aid agencies.

Fourth, the sustainable livelihoods approach focuses on poverty reduction by focusing on people and by converging bottom-up and top-down strategies. It comprises the capabilities, assets (including both material and social resources), and activities required for a means of living. The Department for International Development and the Institute of Development Studies (Knight \& Ward, 2012) seem to follow this approach. Fifth is a local-level development approach that essentially draws on social development ideas, values, and principles (Midgley, 1995). It focuses on comprehensive dimensions and multi-levels. This approach is yet to be widely used in its full or comprehensive form in local communities (Pawar, 2014). Depending on the funding agencies and implementers, all these approaches are used in developing countries. Although the nomenclature of these approaches varies, many of their features are common and some overlap. Thus, many of these approaches can be combined. They all emphasize participation, empowerment, and people-centered development, though to what extent these are practiced in local communities is an open question.

\section{The Purpose of the Study}

The main objectives of this article are to examine broad trends in community practice in Balochistan, and to discuss the imperatives for social workers to engage politically in policy and local communities. It aims to address the core question, 
"What are the broad trends in community practice in Balochistan and do social workers practice in policy and local communities with political engagement?

\section{Research Method}

The data for this study were collected from secondary sources such as books, articles, and reports and the author's observations of and research and reflection on community development projects and policies in Balochistan. The secondary sources were purposively selected depending on their relevance to the objective of the research paper. The data were analyzed by using the qualitative content analysis method.

\section{Results and Discussion}

\section{Lack of Professional Social Work Presence in Local Communities and Particularly in Political Engagement}

Although community practice is undertaken to vary in degrees in Balochistan, both by professionally trained social workers and others who are interested in community development, it appears that such practice appears inadequate relative to the vast number of local-level communities and the severity of their conditions. This is not to suggest that there are no good and successful examples of community practice. Several individuals and organizations have, with passion and commitment, demonstrated effective community development practice.

Similarly, many faith-based (religious) organizations with political affiliations have significantly contributed to community development through a range of health and education provisions. Although these community practitioners are not professionally trained social workers, against all odds they have effectively engaged with people, communities, and politics, and have contributed to community development and to improving the conditions of people in general (Alam, 2008).

Community practice through NGOs, generally social workers' contribution to community practice is minimum and many local-level communities are untouched. Moreover, wherever they are involved in community practice, their political engagement is usually minimal or nil. When there were right opportunities, the author guided and directed a few social workers to engage politically to address the community issue, but the response was not forthcoming. Many social workers' experience suggests that those who have entered local communities without political engagement have often faced significant hurdles, which were mostly created by the dominant community power structures. 
Local political leaders and their politics can make professional social work entry difficult and affect the quality of work in terms of the pace of progress and outcomes. Rudimentary comparison between community practice of professionally trained social workers and of other-than trained social workers suggests that the impact and effectiveness of the latter appear to be far greater or more visible. The author's observation and analysis shows that generally, the social work profession and social workers are not active in community practice in local communities, though one tends to assume that their knowledge and skills are useful in improving community conditions (Ali, \& Baloch, 2015) by facilitating self-help groups, micro-credit schemes, asset-building, social enterprise, and so on. Why do most social workers not undertake community practice at local levels and not engage politically to address core community issues?

Is it because of their professional non-political and non-religious value/principlebase; the kind of knowledge and training provided in the course; Western models of social work education that tilt more toward therapeutic and clinical work; a lack of capability, commitment, and interest; or an unwillingness to move to local communities that are far from their comfort zones and of their preoccupation with individual choice and the material world? Or is it because local communities are complex and difficult, hard to make an entry into and to make a difference as everything is an issue there and altogether they require long-term commitment?

\section{Social Work Practice with Local Communities}

The incredibly nature of the values and principles of social work, such as human rights and social justice preserved in the global definition of social work stated above, and global social work standards (Bano, 2013) suggest that social workers' obedience to such values and principles in practice requires political engagement. It is difficult to imagine the realization of human rights and social justice for local communities without political engagement. Many people in local-level communities live without meeting their basic needs and with deplorable conditions, which suggest that their human rights have been denied and that they are subjected to social injustices. How can social workers engage politically to practice human rights-based and social justice based community practice? Human rights and social justice are not apolitical issues. In seeking to achieve social change, equality, and social justice, it is necessary for social workers to include and address all three types of rights - civil and political; economic, social and cultural; and collective rights - in an interdependent and integrated way, for in community practice all human rights are closely connected (Alan,1996).

The conscious use of human rights values/principles helps to shift the focus from individual and community needs individual and community rights. Such a value orientation and the application of associated principles help workers to focus on 
claims, and to invoke the duties and responsibilities of the state and other social and economic institutions to address these claims of their people and communities. Rights make it clear that violations are neither inevitable nor natural, but arise from deliberate decisions and policies. By demanding explanations and accountability, human rights expose the hidden priorities and structures behind violations and challenge the conditions that create and tolerate poverty.

Gazdar, Haris (1999), states that human rights values focus on social structures, power, rule of law, empowerment, and structural change in favour of the poorest and most deprived. Thus, to be true to their values and principles, social workers need to engage politically with local communities.

\section{Awareness-Raising and Capacity Building}

Awareness-raising and capacity building of the disadvantaged, marginalized, and oppressed groups, and of their organizations and institutions in communities, are essentially political activities. In Hasan, (2009) words, workers need to raise critical consciousness or "conscientization" of people. Raising awareness for awareness sake is of no use if it does not translate into action. It should help develop people's faith in themselves and their ability to think about their rights, the injustices surrounding them, and the structures that cause them, enable them to act so as to transform despair to hope, and dependence to independence. How do you raise that kind of awareness? It cannot be achieved through one-way communication, or spoon-feeding, or blaming people for their situation. It is important to initiate dialogue with people on an equal footing, engage in dialogue that explores and interprets their understandings of the world, and in critical reflection on it, to maintain two-way communication to ensure action (Zaidi, 1999).

To raise awareness and build the capacity of individuals, groups, organizations, and institutions, workers need to facilitate social, cultural, economic, and political development in communities on a sustainable basis. Toward this end, specific groups or categories in local communities need to be identified for awarenessraising and capacity building. Generally, these will include individuals and groups, and particularly marginalized and disadvantaged people, functional leaders, facilitators or catalysts, volunteers, community-based organizations (CBOs), existing or new youth groups, NGOs, and local institutions.

Depending on the need and issue, workers need to identify competent facilitators or volunteers from the community, organize "train the trainer" workshops or sessions, expose people to model community development projects and people engaged in such projects, and draw maximum resources from the community 
(local cultural and religious aspects that can make the point quickly and to which people can relate). Through such political engagement of awareness-raising and capacity building, workers can enable people and communities to initiate the process of transformation of their conditions.

\section{Exploitative and Oppressive Community Power Structures}

Prevailing dominant, autocratic, and dictatorial leadership styles and the concentration of power among a few leaders are critical challenges for most communities in Balochistan. To understand such challenges, it is necessary to look at the whole community as well as specific sections of it. Unnecessary politicization, political processes, and leaders highlighting group divisions are major causes of non-development in many communities. For example, one successful community practitioner states.

Some people who get themselves addressed as the head of a village are afraid of losing power as villagers become united and self-reliant and do not remain dependent on him and stop calling him head. People in politics often fear the idea of empowering villagers who will be able to think on their own and vote. Outside vested interests do not allow the villagers to unite, for the fear of losing their own importance. Disunity is deliberately fostered because of affiliation to different political parties, castes, status etc. Communities cultivated under such a narrowminded leadership style cannot be participatory and people-centered. Hence, altering or changing such leaders across the diverse communities in Balochistan is a challenge for social workers and their community practice.

Due to such leaders and community power structures, most grassroots-level communities, particularly in rural areas, have been experiencing extreme deprivation, oppression and discrimination for a long time. Irrespective of political structures, democratic or otherwise, the current social, economic, and political arrangements are commonly advantageous to local elites and feudal leaders. Existing government bureaucracies often tend to please, or comply with the requirements of these leaders. Hence, any change that aims to alter the current status quo is likely to be resisted by some elements within these grassroots-level communities. The nature of such resistance can be extreme, including violence and deaths, thus causing further violations of human rights.

Owing to such leaders and community power structures, both oppressed and unoppressed community members do not readily come forward to participate in community activities. Such leaders also subvert the democratic process. Poor and marginalized people who have been suppressed and weakened over a long period are not in a position to see beyond their current situation (involving apathy, indifference, helplessness, and powerlessness), and changing that situation is an 
essential task for social workers. To deal with such complex issues and dynamics in communities, social workers, on the one hand, need to tactfully engage with both monolithic pluralistic community power structures and, on the other, enable the oppressed groups to realize that the cause of their situation lies elsewhere in socio-economic and political structures, and that they can change that situation by redefining their conditions and taking responsibility for changing that situation. Breaking the entrenched power structure in communities and altering dictatorial and often violent leadership styles are challenges in many communities.

\section{Sustainable Community Development}

Social workers need to engage politically to ensure sustainable community development, in terms of both ecological and community sustainability. Although both are connected, due to the paucity of space, only community sustainability is discussed. Community sustainability connotes need-based community development activities that can be planned, developed and continued by communities without depending on external support or with minimum external support. Social workers' community practice needs to focus on utilizing the existing capacities and extending the capacities of individuals, groups, leaders, organizations, and institutions in relation to developing participatory mechanisms for self-governance and management without unnecessary external dependence and interference.

Toward this end, they need to engage meaningfully with Community-Based Organizations (CBOs), local NGOs and other associations, and local institutions (councils), which are the main pillars of self-governance and management in communities. By networking among these groups, flexible structures and processes need to be developed for self-governance and management of arrange of community development activities in the areas of health, education, employment, housing, culture, natural resource management, and economic production. For example, in both China and India, decentralizing governance systems to local-level democratic institutions-Villagers' Committees in China and Panchayati Raj in India - has been introduced. Instead of developing parallel governing systems, people in local communities, through CBOs/POs, NGOs, and other associations in coordination and cooperation with these local institutions, can plan and implement village/community development programs and activities.

Although these institutions have democratic structures and are thus avenues for people's participation, their governance systems need to be radically changed and transformed by becoming transparent, honest, open, responsive and accountable to people and themselves. They need to be inclusive of common people and responsive to their voices. Sustainable community development practice should essentially focus on translating these local-level institutions and their written 
commitments into appropriate practice. This may call for amicable dialogue, building trust, cooperation, collaboration, communication and understanding, and at times political activism on the part of people and communities, including social workers, to make these institutions work along the lines intended.

\section{Conclusions}

Social workers struggle for social change, social justice and social development and its motivate individuals, groups and communities to put their political aspect. This research study has conducted to know the nature of the political roles and interventions of social workers. If social workers want a welfare and developed society then they have to effectively influence communities and policy makers in Balochistan. In this regard, they need to be awarded the political context in which actions happen and their positive and negative results. Social work is a career and to virtually have an impact on welfare strategies and structures, and on human rights and social justice, social workers want to be politically minded and politically energetic. Social work is a career and to virtually have an impact on welfare strategies and structures, and on human rights and social justice, social workers want to be politically minded and politically energetic.

As aimed, this article has provided a glimpse of community practice trends in Balochistan and pointed out that professional social workers' contributions to community practice in local communities currently leaves much to be desired as they do not engage politically in their practice as much as they should. The discussion shows clear imperatives for social workers to engage politically with people to transform local community conditions for the better. Social workers need to exit their comfortable neutral zone. The absolute deprived conditions of local communities, oppression of people by community power structures, examples of community practice with political engagement and impactful community practice by other than professional social workers make one wonder, why are social workers and their profession so silent and inactive, notwithstanding values, principles, and commitment enshrined in their code of ethics? Hope this research article helps social workers to reflect critically on this question and act.

\section{References}

Alam, Anwer (2008). Community Development and Social Welfare. Peshawar, Pakistan: New Awan Printers.

Ali, Mumtaz, \& Baloch, Gul.(2015). Community Monitoring in Reproductive Health Project: Case study of Health Sector NGO in Pakistan. VFAST Transaction on Education and Social Science, vol.7:1, pp.1-8. 
Alan M. Shahid. (1996). Community Organizations and Urban Development. Karachi, Pakistan: NGOs Resources Center.

Bano, Nasima. (2013). The Role of AKRSP in Development of Rural Communities of Gilgit Baltistan. PhD Thesis. Islamabad, Pakistan: International Islamic University.

Carey, M. \& Foster, V.L. (2011). Introducing 'Deviant Social Work': Contextualising the Limits of Radical Social Work Whilst Understanding (Fragmented Resistance within the Social Work Labour Process. British Journal of Social Work, vol.43:1, pp.576-593.

Corrigan, P. \& Leonard, P. (1978). Social Work Practice Under Capitalism: A Marxist Approach. London, MacMillan.

Dietz Domanski, M. (1998). Prototypes of Social Work Political Participation: An Empirical Model. Social Work, vol.43, pp.156-167.

Dominelli, L. (2009) Introducing Social Work, Polity Press, Cambridge.

Dominelli, L. (2009a) Introducing Social Work, Polity Press, Cambridge.

Gray, M. (2005). Dilemmas of International Social Work: Paradoxical Processes in Indigenisation, Universalism and Imperialism. International Journal of Social Welfare, vol.14, pp.231-238.

Gray, M. (2005a). Dilemmas of International Social Work: Paradoxical Processes in Indigenisation, Universalism and Imperialism. International Journal of Social Welfare, vol.14, pp.231-238.

Gazdar, Haris. (1999). 'Poverty in Pakistan: A Review , in fifty years of Pakistan's Economy, edited by Shahrukh Rafi Khan. Karachi: Oxford University Press.

Gray, M. \& Webb, S.A. (2009). The Return of the Political in Social Work. International Journal of Social Welfare, vol.18:1, pp.111-115.

Gaha, J. (1999). Promoting Inclusion Redressing Exclusion: The Social Work Challenge. Norma Parker Address, Joint Conference AASW, IFSW, APASWE \& AASWWE, Brisbane, Australia. 
Hoefer, R. (2001). Highly Effective Human Services Interest Groups: Seven Key Practices. Journal of Community Practice, vol.9:2.

Hasan, Mahmood. (2009). Participatory Rural Development in Pakistan: Experiences of Rural Support Programs. Karachi, Pakistan: Oxford University Press.

Harris Rome, S. (2010). Social Work and Civic Engagement: The Political Participation of Professional Social Workers. Journal of Sociology \& Social Welfare, vol.27:3.

International Federation of Social Workers (2000). IFSW News 2/2000. Berne, Switzerland, IFSW.

International Federation of Social Workers (2000a). IFSW News 2/2000. Berne, Switzerland, IFSW.

International Federation of Social Workers (2000b). IFSW News 2/2000. Berne, Switzerland, IFSW.

Ife, J. (1997). Rethinking Social Work. South Melbourne, Australia, Longman.

Johnson, A. (2004). Social Work is Standing on the Legacy of Jane Addams: But are We Sitting on the Sidelines? Social Work, vol.49:2, pp.319-322.

Knight, C. \& Ward, D. (2012), Social Work Education and Training. In: J. Lishman (ed), Social Work Education and Training, London, Jessica Kingsley Publishers. pp. 154 $\square 183$.

Khan, Shahrukh Rafi. (1999). Government, Communities and Non-Govermental Organizations in Social Sector Delivery. Aldershot, U.K: Ashgate.

Lee, J. A. B. (2001). The Empowerment Approach to Social Work Practice. Columbia University Press, New York.

Mullaly, R. (1993). Structural Social Work: Ideology, Theory and practice. Toronto, McClelland and Stewart Inc.

Midgley, J. (1995). Social Development: The Development Perspective in Social Welfare. London, UK: SAGE publications.

Ntusi, T.M. (1998). Professional Challenges for South African Social Workers: Response to Recent Political Changes. Social Work/MaatskaplikeWerk34: 380-388. 
Ntusi TM (1998a). Professional Challenges for South African Social Workers: Response to Recent Political Changes. Social Work/MaatskaplikeWerk34: pp.380-388.

Pawar, Manohar. (2016). Social and Community Development Practice. Delhi, India: Saurabh Printers Pvt. Limed.

Payne, M. (2005) Modern Social Work Theory (Third edition), Palgrave Macmillan, Basingstoke

Pawar, Manohar. (2014). Social and Community Development Practice. Delhi, India: Saurabh Printers Pvt. Limed.

United Nations.(1997).Report on the World social Situation. New York, USA: United Nation Publications.

Zaidi, S Akbar.(1999). The New Development Paradigm: Papers on Institutions, NGOs, Gender and Local Government. Karachi, Pakistan: Oxford University Press.

Dr. Siraj Bashir is an Assistant Professor in the Department of Social Work, University of Balochistan, Quetta, Pakistan.

Dr. Muhammad Faisal Zia is an Assistant Professor in the Department of Social Work, University of Karachi, Karachi, Pakistan.

Prof. Dr. Naheed Abrar is Ex. Chairperson, Department of Social Work, Federal Urdu University of Arts Science \& Technology, Abdul Haq Campus Karachi, Pakistan. 